DOI https://doi.org/10.36059/978-966-397-116-2/147-171

\title{
COMPARATIVE LEGAL ANALYSIS OF CRIMES AGAINST PERSON'S HEALTH OF CERTAIN COUNTRIES OF ROMANO-GERMANIC LEGAL FAMILY
}

\section{Katerynchuk K. V.}

\section{INTRODUCTION}

Health protection is an object of critical infrastructure, one of the state functions in Ukraine as well as in any other state. In Ukraine a holistic organizational-legal system is approved and is functioning at the state level. The basis of state policy in the field of health protection is formed by the Verkhovna Rada of Ukraine consolidating relevant provisions in law. The Criminal Code of Ukraine (hereinafter - the CC) is not an exception.

Each country has the legislation on criminal liability - it is a law containing the norms of criminal-legal nature. The Criminal Codes of all post-Soviet states was built in such a way. There are also states, such as Germany and France, which have a law on criminal liability and other laws regulating criminal-legal issues. Comparison of the Criminal Codes of other states, namely, the main compositions of crimes against person's health, will allow distinguishing certain features, differences between norms and may be of practical interest to the national lawmaker in order to improve it. For this reason there is a need to study the peculiarities of criminal responsibility for crimes against person's health according to the criminal law of countries with the world legal systems of different types (families), and especially the Romano-Germanic type.

Studying the law on criminal liability for infringement on person's health in Romano-Germanic law system, it is worth paying attention to the Criminal Codes of Post-Soviet countries (The Republic of Belarus (hereinafter referred to as Belarus) ${ }^{1}$, the Republic of Moldova

${ }^{1}$ Criminal Code of the Republic of Belarus. №. 275-Z of 9 July, 1999 (as amended up to July 12, 2013). URL: http://cis-legislation.com/document.fwx?rgn=1977. (дата звернення: 20.04.2019 p.) 
$(\text { hereinafter - Moldova) })^{2}$, the Russian Federation (hereinafter - Russia) ${ }^{3}$, the Kyrgyz Republic (hereinafter - Kirghizia) ${ }^{4}$, the Republic of Latvia (hereinafter-Latvia) $^{5}$, the Republic of Lithuania (hereinafter-Lithuania) ${ }^{6}$, the Republic of Armenia (hereinafter - Armenia) ${ }^{7}$, the Rupublic of Kazakhstan (hereinafter - Kazakhstan) ${ }^{8}$, the Republic of Tajikistan (hereinafter - Tajikistan) ${ }^{9}$, the Republic of Estonia (hereinafter Estonia) $^{10}$, the Republic of Uzbekistan (hereinafter - Uzbekistan) ${ }^{11}$, Ukraine $^{12}$ ) and Germany, France, Spain, Austria and Bulgaria.

\section{Comparative Analysis of Criminal-Legal Protection of Person's Health in the Post-Soviet States}

In general, the legislation on criminal liability was influenced by the fact that the above States were a part of a single state for over 70 years. This fact determined the direction of criminal legislation development and, with the proclamation of Ukrainian independence it determined the necessity for its improvement. In studying of the above-mentioned Criminal Codes, the norms of the Special Part, which stipulate criminal liability for crimes against person's health, are researched. In the national

\footnotetext{
${ }^{2}$ Criminal Code of the Republic of Moldova. № 985 of April 18, 2002. (as amended up to November 11, 2016). (MD138). URL: https://sherloc.unodc.org/res/cld/document/criminal-code-of-the-republic-ofmoldova_html/Republic_of_Moldova_Criminal_Code.pdf. (дата звернення: 20.04.2019 p.)

${ }^{3}$ The Criminal Code Of The Russian Federation No. 63-Fz Of June 13, 1996. URL: https://www.wipo.int/edocs/lexdocs/laws/en/ru/ru080en.pdf (дата звернення: 20.04.2019 p.)

${ }^{4}$ Criminal Code of the Kyrgyz Republic No. 68 of October 1, 1997. (as amended up to Law No. 62 of April 21, 2014). URL: https://ihl-databases.icrc.org/applic/ihl/ihl-nat.nsf/0/705a3f3b34f0090ec 12577440047742c/\$FILE/Criminal\%20Code_en.pdf. (дата звернення: 20.04 .2019 p.)

${ }^{5}$ Criminal Code of Latvia, of March 14, 2002, Law No. IX-785 (Last amended on December 23, 2010, by Law No XI-1264). URL: https://likumi.lv/ta/en/id/88966-the-criminal-law. (дата звернення: 20.04 .2019 p.)

${ }^{6}$ Lithuanian Criminal Code, of March 14, 2002, Law No. IX-785 (Last amended on December 23, 2010, by Law No XI-1264). URL: https://wipolex.wipo.int/en/text/202109. (дата звернення: 20.04.2019 p.)

${ }^{7}$ CRIMINAL CODE OF THE REPUBLIC OF ARMENIA OF APRIL 18, 2003. URL: HTTP://WWW.PREVENTGENOCIDE.ORG/AM/CRIMINALCODE.HTM. (ДATA ЗВEPHEHНЯ: 20.04.2019 P.)

${ }^{8}$ The Code of the Republic of Kazakhstan dated 3 July 2014. № 226-V of the Law of the Republic of Kazakhstan. URL: https://wipolex.wipo.int/en/text/407059. (дата звернення: 20.04.2019 p.)

${ }^{9}$ Criminal Code of the Republic of Tajikistan. URL: http://cis-legislation.com/document.fwx?rgn=2324. (дата звернення: 20.04.2019 р.)

${ }^{10}$ Penal Code of the Republic of Estonia (consolidated text of January 1, 2012). URL: https://wipolex.wipo.int/en/text/432563. (дата звернення: 20.04.2019 p.)

${ }^{11}$ Criminal Code of the Republic of Uzbekistan 1994 (as amended up to Law of the Republic of Uzbekistan No. 93 of April 25, 2007). URL: https://sherloc.unodc.org/res/cld/document/criminal-code-of-therepublic-of-uzbekistan_html/Uzbekistan_Criminal_Code_1994.pdf. (дата звернення: 20.04.2019р.)

${ }^{12}$ Кримінальний кодекс України від 5 квіт. 2001 № 2341-ІІІ // Відомості Верховної Ради України. 2001. № 25-26. Ст. 131 (редакція від 26.02.2019 p.). URL: http://zakon3.rada.gov.ua/laws/show/2341-14.
} 
criminal law, they are united in section II "Crimes against person's life and health".

Intentional grave physical injury has certain differences in comparable Criminal Codes. Thus, according to the Criminal Code of Russia (Article 111), Armenia (Article 112), Tajikistan (Article 110), in contrast to the Criminal Code of Ukraine (Article 121), a list of features of intentional grave physical injury includes a mental disorder (this feature is present solely in the CC of Russia), drug addiction or substance abuse as well; consciously full loss of professional working capacity for a guilty person. The $\mathrm{CC}$ of Lithuania, defining features of physical injuries in Articles 135, 138, 139, establishes their "specific" features - this is the loss of most of professional or general working capacity by a person. Such features, in our opinion, are unacceptable, since, firstly, it is not determined which part of loss of working capacity exactly, so, it is not defined as a percentage (33\%), as in the Criminal Code of Uzbekistan (Article 104) or in a partial (1/3) meaning; and secondly, the "stability" of such working capacity loss is not defined. The next discussion point of Article 135 of the Criminal Code of Lithuania is a serious or lasting disease, which is a real threat to life. This feature, in our opinion, includes HIV/AIDS, other incurable infectious diseases and sexually transmitted diseases, as there are no articles in the Criminal Code of Lithuania providing criminal liability for such deeds.

The Criminal Code of Estonia (Article 107) determines mental illness as one of the features. The current Criminal Code of Ukraine no longer uses this terminology, but the Rules of forensic definition of the degree of physical injury gravity contain this term.

The Criminal Code of Moldova (Article 151) distinguishes and specifies the consequences - irrecoverable mutilation of face and (or) adjacent areas (zones). The same situation is in the Criminal Code of Belarus (Article 147) with the only difference: a health disorder, associated with trauma of the spine bones for a period of more than four months, or that was manifested in irrecoverable mutilation of face or neck. So, the structural differences between comparable articles are that some of them include consequences that are "positive" in our opinion and have to be implemented in the Criminal Code of Ukraine. We should pay attention to one of consequences placed in the Criminal Code of Moldova, Belarus which is "irrecoverable mutilation of face and (or) adjacent 
areas". In comparison with the article of the Criminal Code of Belarus, which specifies only the neck, we believe that such specification is inappropriate, because not only the parts/areas (in addition to face and neck), such as the face and neck, can suffer as a result of the criminal deeds, but also, the ears, hair covering of the head, which in the future may affect not only the physiological, but also on the mental state of a person, especially in the case of females. Criminal Code of Uzbekistan in Article 104 defines this feature as irrecoverable mutilation of the body.

The lawmaker in the Criminal Code of Russia also distinguishes drug addiction or substance abuse as one of the crime consequences. In addition, the same norm of the Criminal Code of Russia provides a complete loss of professional working capacity. The previous CC of Kazakhstan (Article 103) also identified one of the features of grave physical injury as a complete loss of professional working capacity, but this "goes beyond the scope of forensic examination and for its establishment it is necessary to involve the commission of experts according to the victim's profession" 13 . The Criminal Code of Belarus distinguishes the intentional deprivation of professional working capacity in a separate article (Article 148). The articles of the Criminal Code of Ukraine do not have such feature, but the amount of lasting loss of working capacity is determined taking into account the regulatory criteria defined by the Ministry of Health for establishing the degree of lasting loss of professional working capacity in percentage and does not belong to the duties of forensic medical experts.

Regarding the intentional physical injury of middle gravity, we should note that the features of these articles are that the Criminal Code of Belarus (Article 149) specifies a prolonged health disorder for up to four months, as opposed to other comparable CCs. Commented Criminal Code of Belarus in Article 149 sets the time for damage to the spine bones as 122 days. Such position is provided in clause 15 of the Rules of forensic examination of the nature and gravity of physical injuries in the Republic of Belarus ${ }^{14}$. Instruction on the procedure for conducting forensic examinations concerning the determination of gravity of physical injuries

\footnotetext{
${ }^{13}$ Абдрашит А. А. Уголовная ответственность за умышленное причинение тяжкого вреда здоровью по законодательству Республики Казахстан: автореф. дис. ... канд. юрид. наук: спец. 12.00.08 «Уголовное право и криминология; уголовно-исполнительное право». Саратов: Акад. МВД Республики Казахстан. 2004. 24 с.

${ }^{14}$ Кухарьков Ю. В., Самойлович М. В. Судебно-медицинская експертиза характера и степени тяжести телесных повреждений: учебно-метод. пособие. Минск, 2003. С. 13.
} 
in the Republic of Belarus in clause 24.10 states that, with the longer course of trauma of skeleton bones the physical injury should be assessed as grave ${ }^{15}$. The Criminal Code of Moldova (Article 152) and Lithuania (Article 139) contain an intentional physical injury of middle gravity or middle gravity of health damage. "The provisions of this article are not clear enough, since their simultaneous application violates the requirements for the law conciseness and is unnecessary, because the second one covers the first" ${ }^{\prime \prime}$.

Criminal Code of the abovementioned countries in the list of articles of crimes against person's health contain an article establishing criminal liability for intentional grave physical injury caused in a state of intense emotional distress. In the Criminal Code of Ukraine this is Article 123. Comparing the codes, these articles have some discrepancies. The Criminal Code of Russia (Article 113), Belarus (Article 150), Kirgizia (Article 106), Armenia (Article 114), Kazakhstan (Article 111), Tajikistan (Article 113) and Moldova (Article 156), the dispositions other than those which suddenly arose as a result of unlawful violence or severe abuse on the part of the victim, indicate also the infliction of other illegal or immoral actions of the victim. In addition, the codes of Armenia, Kazakhstan, Russia and Belarus indicate that such behavior of the victim (mentioned above) arose as a result of a long traumatic situation. In the Criminal Code of Latvia (Article 127) it is legally determined that a state of intense emotional distress may arise as a result of "violence or a serious abuse of honor from the victim's side". The CC of Lithuania (Article 136) defines the condition of a intense emotional distress as "an unlawful deed on the part of the victim or a particularly strong abuse against them or their close person", and the CC of Armenia - which arose as a result of outrages.

Features of some articles of the Criminal Code and in the consequent consequences set forth in either one part of the article, or in different parts:

The Criminal Code of Lithuania - disfigurement or grave harm;

\footnotetext{
${ }^{15}$ Инструкция о порядке проведения судебно-медицинской экспертизы по определению степени тяжести телесных повреждений от 24 мая 2016 г. № 16. URL: http://www.pravo.by/upload/docs/op/ T21603582_1475096400.pdf.

${ }^{16}$ Хавронюк М. І. Кримінальне законодавство України та інших держав континентальної Європи: порівняльний аналіз, проблеми гармонізації. Київ: Юрисконсульт, 2006. С. 664.
} 
The Criminal Code of Armenia, Tajikistan - part 1 - harm of middle gravity, and in part 2 - grave harm to health;

The Criminal Code of Kyrgyzstan (Article 106) and Latvia (Article 127), Uzbekistan (Article 106) - grave or less grave harm to person's health or grave or physical injury of middle gravity. The same situation is with regard to the consequences in the Criminal Code of Kyrgyzstan (Article 107) and Latvia (Articles 128, 129) in case of exceeding the limits of necessary defense or in case of exceeding the measures necessary for the detention of a criminal, in contrast to the Criminal Code of Ukraine (Article 124 "Intentional grave physical injury in excess of the limits of necessary defense or in case of exceeding the measures necessary for detention of a criminal"). Analyzing the articles, we divided them into groups: depending on the consequences caused; circumstances that exclude the criminality of the deed, and their structural placement in the articles of the Criminal Code.

1. In some countries, a lawmaker distinguishes different circumstances that exclude the criminality of a deed in some articles with the establishment of the same consequences (grave or physical injuries of middle gravity), examples of which are articles of the Criminal Code of Latvia (Articles 128, 129), Kazakhstan (Articles 112, 113), Armenia (Articles 115, 116), Uzbekistan (Articles 107, 108), Kirghizia (Articles 107, 108), the Criminal Code of Estonia (Articles 110, 111).

2. In some countries, a lawmaker distinguishes these circumstances in various articles of the Code with the establishment of various consequences - the Criminal Code of Belarus (Articles 151, 152) and the Criminal Code of Tajikistan, for example, in Article 114 - this is an intentional causing of grave harm to health, committed in excess of the limits of the necessary defense, and in Article 115 for intentional harm of middle gravity (part 1) or grave (part 2) harm to the health of the person who committed a crime in case of exceeding the measures necessary for the detention of a criminal.

3. Different parts of the article determine different circumstances and set different consequences, for example, in the Criminal Code of Russia (Article 114), part 1 - grave harm to health in case of exceeding the limits of necessary defense, part 2 - grave or harm of middle gravity to person's health in case of exceeding the measures necessary for the detention of a criminal. 
4. Circumstances that exclude the criminality of a deed are indicated in different parts of a single article with the same consequences, for example, Article 124 of the Criminal Code of Ukraine.

5. Some Criminal Codes do not define a criminal punitive deed in case of exceeding the necessary defense or in case of exceeding the measures necessary for the detention of a criminal - the Criminal Code of Moldova and Lithuania.

Part 1 of Article 125 "Intentional trivial physical injury" of the Criminal Code of Ukraine, Part 1 of Article 112 "Intentional causing of trivial harm to health" of the Criminal Code of Tajikistan, the Criminal Code of Kirghizia (Article 117) establishes criminal liability for causing a short-term health disorder or a minor loss of working capacity. Differences between the Criminal Code of Ukraine are in the fact that in the Criminal Code of Kirghizia, Tajikistan it is about the loss of "minor persistent" working capacity, and the Criminal Code of Russia (Part 1 of Article 155) and Belarus (Article 153), Armenia (Article 117) specifies, namely: minor persistent working capacity should be general, and not any other.

The peculiarity of the Criminal Code of Latvia in Part 1 of Article 130 and the Criminal Code of Estonia in Article 113, in addition to the features of trivial physical injury, the law also recognizes deeds that do not result in these consequences. Such "addition" includes the features that in the Criminal Code of Ukraine are included in the composition of the crime of "blows" stipulated in Part 1 of Article 126. Part 3 of Article 130 of the Criminal Code of Latvia provides for criminal liability for "systematic blows having the nature of torment or other torment, which did not lead to grave physical injury or physical injury of middle gravity". Thus, the Criminal Code of Latvia (Article 130 "Trivial physical injury"), Lithuania (Article 140 "Causing pain or trivial physical injury"), Estonia (Article 113 "Violent actions against a person") provides for liability for the specified consequences and deeds, which can cause pain to the person, such as blows and torment.

In some post-Soviet codes, such as the Criminal Code of Tajikistan, Estonia, this article does not provide qualifying features, as in the Ukrainian Criminal Code.

Part 2 of Article 155 of the Criminal Code of Russia contains qualifying features of intentional trivial physical injury, namely: a) from 
hooligan motives; b) for motives of political, ideological, racial, national or religious hatred or hostility or from the motives of hatred or hostility in relation to any social group. The Criminal Code of Kazakhstan decriminalized deeds providing criminal liability for the trivial harm to person's health (Article 108) and blows (Article 109) ${ }^{17}$.

Blows and torment. Article 126 of the Criminal Code of Ukraine provides for criminal liability for blows and torment. Part 1 has identified blows as intentional hits, blows or other violent acts that caused physical pain and did not cause physical injury. In the Criminal Code of Russia (Article 116), Kirghizia (Article 100), Tajikistan (Article 116), the article "Blows" refers to blows or committing other violent acts that caused physical pain but did not cause any consequences - trivial harm to the health. The Criminal Code of Armenia (Article 118) does not define the consequences in the article - pain or physical pain, in contrast to the above-mentioned codes.

In the Criminal Code of Belarus in Article 154 "Torment" provides for responsibility for "intentional causing of prolonged pain or torment in ways that cause particular physical and mental suffering of a victim, or systematic blows that have not caused grave and less grave physical injury". The Criminal Code of Ukraine also provides for criminal liability for torment in Part 2 of Article 126 "The same acts that have the nature of a torment committed by a group of persons, or in order to intimidate the victim or their relatives or on grounds of racial, national or religious intolerance". And the Criminal Code of Russia (Article 117), Tajikistan (Article 117) "Causing physical or mental suffering through systematic blows or other violent actions, if it did not cause grave or harm of middle gravity to health". So, here in case of causing trivial physical injuries (trivial harm to health), the actions of a guilty person are covered by this article.

The criminal Code of Moldova does not provide for criminal liability for blows and (or) torment.

Analysis of the articles of the Criminal Code of Ukraine and the postSoviet states, which provide for criminal liability for blows, shows their certain distinctive features. Only the Criminal Code of Ukraine in the disposition of Article 126 contains one of the methods of blows - a hit.

\footnotetext{
${ }^{17}$ О внесении изменений и дополнений в некоторые законодательные акты Республики Казахстан по вопросам совершенствования правоохранительной системы // Закон Республики Казахстан от 3 июля 2017 г. URL: № 84-VI. https://zakon.uchet.kz/rus/docs/Z1700000084\#202.
} 
At the same time, the Criminal Code of Russia, Kirghizia, Tajikistan does not have such a concretization. Moreover, the Russian lawmaker in determining the consequences (physical pain) notes the mandatory absence of trivial harm to health, Ukrainian legislature - physical injuries (any of them). Qualifying features of Article 116 (Part 2) of the Criminal Code of Russia provides for a deed committed: a) on hooligan motives; b) on motives of political, ideological, racial, national or religious hatred or hostility or on motives of hatred or hostility to any social group. The Criminal Code of Ukraine in Part 2 of Article 126 provides for liability for the same deeds that have the nature of torment committed by a group of persons, or in order to intimidate the victim or their relatives or on motives of racial, national or religious intolerance. The Criminal Code of Russia establishes grounds with a certain distinction, namely: political, ideological, racial, national or religious hatred or hostility, or on motives of hatred or hostility to any social group.

As for the differences between the articles providing for criminal liability for torment, the Criminal Code of Ukraine (Part 2, Article 126), Russia (Part 1, Article 117) and Belarus (Part 1, Article 154) have certain peculiarities, namely: 1) according to the Criminal Code of Ukraine, this crime is considered to be terminated from the moment of the consequences onset - physical pain; according to the Criminal Code of Kazakhstan (Article 110) - causing physical or mental suffering and trivial physical injury; the Criminal Code of Russia (Article 117), Tajikistan (Article 117), Kirghizia (Article 111) - causing physical or mental suffering and trivial physical injuries; Belarus (Article 154) - the onset of prolonged pain or suffering, caused by methods that cause particular physical and mental suffering, trivial physical injury; Uzbekistan (Article 110) - causing trivial physical injuries.

The commentary to the Criminal Code of the Republic of Belarus states that systematic to cause the liability for torment (Article 154) it is necessary to cause blows systematically. The systematic nature means that a person committed more than two identical or homogeneous offenses. So, in this case, the crime is terminated from the moment when blows take place for the third time ${ }^{18}$. The following are the actions associated with multiple or prolonged pain belonging to torment: pinching, flogging,

\footnotetext{
${ }^{18}$ Комментарий к Уголовному кодексу Республики Беларусь / Н. Ф. Ахраменко, Н. А. Бабий, А. В. Барков и др.; под общ. ред. А. В. Баркова. Минск: Тесей, 2003. С. 30.
} 
causing multiple but minor injuries with blunt or sharp objects, the effects of thermal factors, and other similar actions (clause 23) ${ }^{19}$. Torment will take place in case when they are repeatedly executed for the purpose of causing particularly painful feelings, physical or mental suffering to the victim, they have nature of torture ${ }^{20}$.

Torture As a result of a comparative analysis of the post-Soviet Criminal Code articles, we came to the conclusion that torture as an independent article is provided in the Criminal Code of Ukraine (Article 127 "Torture"), Armenia (Article 119 "Torture"), Moldova

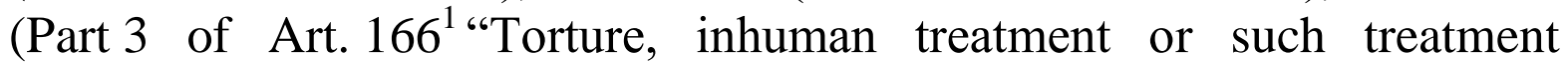
humiliating dignity"), Belarus (Article 128 "Crimes against the safety of mankind") ${ }^{21}$. Their main features are distinguished. Lawmakers of Moldova, Belarus, Armenia, and Ukraine point the features of torture are pain and suffering. The Criminal Codes of the Russian Federation (note to Article 117), Kazakhstan (Article 146), and Tajikistan (Article 143 ${ }^{1}$ ) indicate the definition of torture and establish only one feature - suffering (physical and psychological). Thus, the lawmaker does not call pain as a feature of torture that in our opinion, greatly narrows this concept. Therefore, in case of implementation of such deeds that cause pain, the qualification of deeds under this article is excluded, because the scientists refer the concept of "pain" and "suffering" to the different categories.

In addition, the Criminal Codes of Ukraine, Moldova, in contrast to other mentioned codes, "strengthen" some features of torture, namely, "causing severe pain and suffering", although it does not affect qualification. The Criminal Code also specifies a special purpose. In the Criminal Code of Ukraine - compelling the victim or another person to take actions that contradict their will, including obtaining from them or another person information or recognition, or in order to punish them or another person for acts committed by them or another person or in the commission of which they or another person are suspected, as well as in order to intimidate or discriminate against them or other persons; the

\footnotetext{
${ }^{19}$ Правила судебно-медицинской экспертизы характера и тяжести телесных повреждений в Республике Беларусь от 14 нояб. 1991 г. № 200. URL: http://pravoby.info/docum09/part36/akt36157.htm

${ }^{20}$ Комментарий к Уголовному кодексу Республики Беларусь / Н. Ф. Ахраменка, Н. А. Бабий, А. В. Барков и др.; под общ. ред. А. В. Баркова. Минск: Тесей, 2003. С. 294.

${ }^{21}$ Катеринчук Е. В. Проблемы соответствия уголовного законодательства в сфере запрета пыток международным стандартам // Идеал свободной человеческой личности: от международних пактов о правах человека к современной Конституции: материалы Междунар. науч.-практ. конф. (м. Минск, 16 дек. 2016 г.). Акад МВД Республики Беларусь. 2016. С. 76-78.
} 
Criminal Code of Russia - an inducement to witness or other actions that contradict the will of a person, as well as for the purpose of punishment or for other purposes. Analyzing this provision, it remains unclear why the lawmaker of Russia tries to establish the purpose of torture, and then abstracts it with the terms "other actions" and "other goals"; the Criminal Code of Belarus - the receipt of information or recognition from them or from a third person, the punishment of them for the action which they committed or the third person or for which they are suspected, as well as intimidation or coercion of them or a third person or for any other reason using discrimination of any nature; the Criminal Code of Moldova means receiving from them or from a third person information or confession, punishment of them for their action, committed by them or a third person or in the execution of which they are suspected, intimidation or coercion of them or a third person or for any other reason based on discrimination of any kind, if such pain or suffering is caused by an official or other person acting in an official capacity or from incitement, or with their knowledge or tacit consent, with the exception of pain or suffering arising exclusively from the law sanctions, inseparable from these sanctions or caused by them by chance. The article of the Criminal Code of Armenia does not define the goal of this crime.

The Criminal Code of Ukraine indicates blows, torment or other violent actions as the ways of torture; Armenia - blows or other violent actions. There are no ways mentioned in the Criminal Code of Russia, Belarus, Kazakhstan, Tajikistan and Moldova.

The subjective features are different too, namely, the subject of crime of "torture". In the Criminal Code of Kazakhstan (Article 146), Tajikistan (1431), unlike other provisions of the Criminal Codes, there is an investigator or another official, a person who conducts an investigation. Such feature shows that the given codes, in contrast to the Ukrainian and other codes are close to the provisions of international normative legal acts ratified by Ukraine.

So, torture as an independent crime composition is foreseen only in some of the Criminal Codes analyzed by us. In articles where the features of torture were identified, we found the following differences: an alternative goal or its absence, ways of committing torture or their absence, "specific" qualifying features. 
Careless grave or physical injury of middle gravity (Article 128 of the Criminal Code of Ukraine). When comparing the disposition of the articles, it was found that the Criminal Code of Belarus (Article 155), Moldova (Article 157), and Ukraine do not have any particular differences. The Criminal Code of Russia (Article 118) provides for liability only for causing grave physical injury by negligence, also this article has Part 2, which establishes liability for the same deed committed as a result of improper performance of professional duties by a person.

The distinctive features in this aspect are the provisions of the Criminal Code of Lithuania (Articles 137, 138), Tajikistan (Articles 118, 119) and Armenia (Articles 120,121) providing for criminal liability for grave and minor gravity harm to person's health in different articles. The Criminal Code of Kazakhstan in four parts determines as criminal punishable deeds the following: causing middle gravity harm to health by negligence (Part 1, Article 114); causing middle gravity harm to health by negligence to two or more persons (Part 2 of Article 114); causing grave harm to health by negligence (Part 3 of Article 114); causing grave harm to health by negligence for two or more persons (Part 4 of Article 114).

Contamination with human immunodeficiency virus or other incurable infectious disease. The distinctions in the Criminal Code of Russia (Article 122), Moldova (Article 212), Estonia (Article 1192), Belarus (Article 157), Armenia (Article 123) and Ukraine (art. 130) are as follows: firstly, in the fact that the Criminal Code of Moldova and Estonia use the term AIDS, as opposed to the other Criminal Codes; secondly, the Criminal Code of Ukraine establishes liability not only for the contamination with a human immunodeficiency virus, but also for the person's contamination with another incurable infectious disease, which is dangerous for human life; thirdly, the Criminal Code of Russia (Part 3 of Article 122), Kirghizia (Part 4 of Article 117) and Moldova (Part 4 of Article 212) establish a special subject of a crime - a medical employee, due to non-performance or improper performance of their professional duties; fourthly, in the Criminal Code of Armenia, the qualifying feature of this article is the contamination of a pregnant woman intentionally.

The legislation of some countries, the Criminal Code of Russia (Article 122), the Criminal Code of Moldova (Article 212), the Criminal Code Kazakhstan (Article 118. Note) provides for the possibility of exemption from criminal liability in connection with the consent of the 
victim to put them in danger of contamination or HIV contamination by a person who has known about a virus. In the Criminal Code of Latvia (Article 133) there are no defined incentive or qualifying norms and especially qualifying features, there is no reference to "other incurable infectious diseases". Criminal liability arises only in the case of "intentional contamination of a person with a human immunodeficiency virus (HIV)". In the Criminal Code of Estonia in Article $119^{1}$, it is indicated that a person who avoids the treatment of a sexually transmitted disease can be brought to liability. At the same time, the Criminal Code of Ukraine does not recognize such deeds as criminal, but Article 45 "Avoidance of the examination and preventive treatment of people with sexually transmitted disease" of the Code of Ukraine on Administrative Offences $^{22}$ defines it as a law offence.

Criminal Law of Uzbekistan in Article 113 determines such deed as criminal which causes the spread of a sexually transmitted disease or AIDS. Firstly, one article contains two norms, and secondly, AIDS is the final stage of human immunodeficiency virus disease. In addition, deeds leading to "another incurable infectious disease" are not determined as criminal ones.

Criminal liability also arises for contamination with sexually transmitted disease. The differences in the articles of comparable codes are that the Criminal Code of Belarus (Article 158) and Estonia (Article 119) establish liability for intentional placing another person in danger of contaminating with a sexually transmitted disease by a person who has known about this disease, noting about the way of committing a crime - through sexual intercourse or other actions. In the Criminal Code of Armenia, in addition to contamination with a sexually transmitted disease, "other sexually transmitted infections" are foreseen.

\section{Criminal-Legal Protection of Person's Health in Other Countries of Romano-Germanic Legal Family}

Another representative of the Romano-Germanic type is the Criminal Code of Germany", in section 17 "Criminal deeds against physical inviolability" the following types of physical injury are distinguished:

\footnotetext{
${ }^{22}$ Кодекс України про адміністративні правопорушення (редакція від 26 жовт. 2017 р.) // Відомості Верховної Ради Української РСР. 1984, додаток до № 51. Ст. 1122.

${ }^{23}$ Criminal Code of Germany (2013). URL: https://www.gesetze-im-internet.de/englisch_stgb/ englisch_stgb.html\#p0012 . (дата звернення: 30.09.2017 p.)
} 
physical injury, dangerous and grave physical injury. The peculiarity of these articles is that $\S 223$ "Physical injury" provides for liability for causing physical injury to another person or harm to their health. The second type in $\S 224$ "Dangerous physical injury" is distinguished from the previous article by the following means: by use of poison or other substances harmful to health; by use of weapons or other dangerous gear; with a treacherous attack; together with another person; through lifethreatening treatment. In $\S 226$, "Grave physical injury", the features of this injury are indicated: loss of vision on one or both eyes, hearing, speech or ability to childbirth; the loss of an important organ of the body or a long period of inability to use it or to remain largely distorted or become a chronically sick person, paralyzed, or mentally ill or have any physical or mental deviations. Therefore, comparing the provisions of the Criminal Code of Ukraine and Germany, certain features can be distinguished; firstly, the Criminal Code of Germany distinguishes such feature as the loss of childbirth ability by the victim. It is also noted that as a result of a physical injury, the victim is to a large extent and for a long time remains distorted or becomes chronic, paralyzed, or has a mental illness or any physical or mental deviations. In the case of a physical injury caused the death of a victim, criminal liability arises under $\S 227$ "Physical injury that caused death". The lawmaker in $\S 228$ provides for liability for physical injury, with the consent of a victim, with the mandatory condition that the person acts illegally only if the deed, despite the consent of a victim, violates generally accepted moral practices. Apart from guilt in the form of intent, the CC of Germany also foresees crimes committed by negligence. One of the examples is $\S 229$ "Physical injury caused through neglect". In some cases, the articles of the German Criminal Code cover procedural issues. For example, intentional infliction of physical injuries or through neglect are prosecuted only by claim, except in those cases where the prosecution authorities find it necessary that intervention was received from the relevant authority because of a particular public interest ( $§ 230$ "Victim's claim"). The issues of such nature are mentioned in the Criminal Procedural Code of Ukraine in Chapter 36, "Criminal proceedings in the form of a private prosecution". In $\S 225$, "Abuse of persons under wardship" of the Criminal Code of Germany, a lawmaker specifies a special victim (a person who has not reached the age of eighteen, or a person who is 
defenseless as a result of illness or physical disability, who: 1) is under their care or under their protection; 2) belongs to their family; 3) is provided at their disposal by a person obliged to provide material assistance to them; 4) was subordinate to them in the framework of official and working relations. This clause also provides for punishment for torment or torture, intentional neglect of personal duties to take care of a persons causing harm to their health. Qualifying features are death, grave harm to health, causing significant harm to physical or spiritual development. Participation in a fight or an attack committed by several persons is punishable only for the participation provided for in $\S 231$. So, German criminal law does not provide for other types of physical injury, blows and torment, as well as special types of physical injury.

The Criminal Code of France ${ }^{24}$, chapter II, "On infringement on physical or mental inviolability of a person", section 1, "On intentional infringement of inviolability of a person", provides for liability for torture or acts of cruelty (Article 222-1). If these actions were taken in relation to a minor who has not reached the age of fifteen (clause 1, Article 222-3); to a person whose special vulnerability due to the age, illness, injury, physical or mental defects or in the state of pregnancy is obvious or known to the executor (clause 2, Article 222-3); in relation to a relative on the ascending line or adoptive parent or mother (clause 3 of Article 222-3). The qualifying features mentioned are the most grave as for gravity degree compared with others that provide for a special victim (magistrate, juror, lawyer, public servant, representative of the law, commissioner of justice, gendarmerie officer, national police officer, customs officer, penitentiary administration, any other person who has been given public authority or a person entrusted with the duty of public service in the performance of or in connection with the performance of these functions or duties, if such status of a victim is apparent or known to the executor (clause 4 Article 222-3); witness, victim, civil plaintiff (clause 5, Article 222 -3). The same article also provides for a special subject of a crime - a spouse or a person who lives with a victim in a civil marriage (clause 6, Article 222-3), a person possessing public authority or a person who performs duties in the civil service (clause 7 Article 222-3). Separate clause 8 of this article provides for punishment for the implementation of the above actions in

\footnotetext{
${ }^{24}$ Criminal Code of the French Republic (as of 2016). URL: https://eige.europa.eu/gender-basedviolence/resources/france/french-penal-code-general-criminal-law-articles-221-2-222-3-222-5-222-10. (дата звернення: 20.04.2019р.)
} 
complicity, with the intention (clause 9, Article 222-2) and with the use or threat of use of weapons (clause 10, Article 222-2). Article 222-4 specifies the victim and the way of committing a crime provided in Article 222-1 - systematically in relation to a minor who has not reached the age of fifteen, or a person whose vulnerable position is obvious or known to the executor according to age, illness, injury, physical or mental defects or in the state of pregnancy. Using torture or acts of cruelty with consequences in the form of injuries or chronic diseases, liability arises according to Article 222-5 of the Criminal Code of France, and in case of consequences in the form of death by negligence - according to Article 222-6.

In $\S 2$ "On violent actions" the Criminal Code of France points to violent actions caused death (Article 222-7); violent actions caused injury or chronic disease (Article 222-9); violent actions caused total loss of working capacity (Article 222-11); violent actions resulted in loss of working capacity for a period less or equal to eight days (Article 222-13); systematic violent actions (Articles 222-14). In case of the prescription of harmful substances as medicines that caused harm to the physical or mental inviolability of another person, the liability arises according to Article 222-15. So, in criminal law of France, a lawmaker does not distinguish the types of physical injury in the article, as it is made in the Criminal Codes of the post-Soviet countries.

In addition, the Criminal Code of France contains articles providing for liability for threatening a person to commit any actions or actions mentioned above (Articles 222-17) in any way (Article 222-18). Moreover, the Code of France determines qualifying features in certain articles or clauses that are repeated in the articles described above. Thus, the provisions of Article 222-3 are reflected in Articles 222-8, 222-10, 222-12 and 222-13 with certain peculiarities, first of all, they are used in articles that refer to physical injuries, and secondly, only Articles 222-12, 222-13 have identical clause 11, which indicates the place where the crime was committed, namely: educational and fostering institution, and Article 222-14 mentions the way - systematic violent actions.

"Deeds determined as criminal infringements on mental inviolability are not only threats, but also sound aggressions, for example, committed repeatedly in order to disturb the rest of a person, "unfriendly" phone calls (Article 222-16). As for the threat, then, the threat to commit the 
following is punishable: a) any crime or misconduct against a person whose attempt is punishable if committed repeatedly or in material form (Article 222-17); or b) any crime or misconduct against a person accompanied by an order to fulfill the condition, regardless of the way ${ }^{25}$. "Unintentional infringement on person's inviolability" is placed in section II. The features of these crimes are that a lawmaker of France also distinguishes physical injury through negligence: 1) full loss of working capacity (Article 222-19); 2) full loss of working capacity of another person for a period of less than or equal to three months (Article 222-20). In Article 222-21 a special subject is determined - a legal entity, for actions specified in Article 222-19 and 222-20.

The Criminal Code of $\operatorname{Spain}^{26}$ in section III "Physical injuries" in part 1 of Article 147 defines and provides punishment for injuries violating physical inviolability, physical or mental health. In case of less grave harm, criminal liability is stipulated in Part 2 of Article 147 of the Criminal Code of Spain. The features of grave physical injury: loss or injury of a significantly important organ or limb or organ of sense, impotence, infertility, grave disfigurement, mental or physical illness are provided by Article 148 of the Criminal Code of Spain. Other features, such as loss or injury of a less important organ or limb or deformity are stated in Article 150 of the Criminal Code of Spain. Analysis of the provisions of these articles leads to the conclusion that Article 148 of the Criminal Code of Spain refers to grave physical injury, and Article 150 of the Criminal Code of Spain determine the features of physical injury of middle gravity. However, in our opinion, there can be no organs in the human body that have certain criteria of "importance" or "no importance". Each organ performs certain functions in the human body and its loss or organ inability to perform certain functions leads to negative changes throughout the whole body. In addition, in comparison with some provisions of the Criminal Code of Ukraine, there are no other fundamentally essential features of grave physical injury. Article 152 of the Criminal Code of Spain determines physical injuries caused by negligence.

\footnotetext{
${ }^{25}$ Хавронюк М. І. Кримінальне законодавство України та інших держав континентальної Свропи: порівняльний аналіз, проблеми гармонізації. Київ: Юрисконсульт, 2006. С. 669.

${ }^{26}$ Penal Code of Spain (Organic Law No. 10/1995 of November 23, 1995, as amended up to Law No. 4/2015 of April 27, 2015). URL: https://wipolex.wipo.int/en/text/507602. (дата звернення: 20.04.2019 p.)
} 
Unlike national criminal law, the Criminal Code of Spain provides for liability in case of physical injury with the lawful voluntary consent of the victim (Article 155 of the Criminal Code of Spain). The Criminal Code of Ukraine does not contain such provisions, except for Article 409 "Avoidance of military service by self- disfigurement".

Article 630 of the Criminal Code of Spain does not define the name or stage of diseases, at the same time, it is stated that someone who leaves syringes or other dangerous instruments in a way or in such circumstances that they can harm people or contaminate with diseases or in places that are often visited by minors is subject to criminal liability.

In Spain, in the middle of $70 \mathrm{~s}$, the process of democratic transformation was embodied in one of the most important legal documents of contemporary European history - the Constitution of $1978^{27}$, having become the basis for the reforms in all domains of life: economic, social, political and legal. Along with the proclamation of human fundamental rights and freedoms, this Constitution contains a number of provisions that directly regulate the issue of criminal liability. Article 15 of the Constitution of Spain defines an absolute ban as "no one can ever be subjected to torture, cruel or inhuman or humiliating punishment". Therefore, section VII, "Torture and other crimes against mental inviolability" contains a whole number of articles (Article 173-177 of the Criminal Code of Spain) against the use of torture not only by a general subject, but also a special one. The next peculiarity of this section is that a lawmaker has determined that in case of causing physical injuries or harm to the life, physical inviolability, health, sexual freedom or property of the victim or a third person, such action is punished separately (Article 177 of the Criminal Code of Spain). This way, it simplified the qualifications and made competition of norms impossible.

The Criminal Code of Austriai ${ }^{28}$ in par. $1 \S 83$ provides for criminal liability for physical injury or harm to health with intent. In par. $2 \S 83$ a list of features of physical injury is provided. The norm contains

\footnotetext{
${ }^{27}$ Spanish Constitution of 1978 «Constitution passed by the Cortes Generales in plenary meetings of the Congress of Deputies and the Senate held on October 31, 1978. Ratified by referendum of the Spanish People on December 7, 1978. Sanctioned by his majesty the King before the Cortes Generales on December 27 , 1978».URL:http://www.congreso.es/portal/page/portal/Congreso/Congreso/Hist_Normas/Norm/const_espa_tex to_ingles_0.pdf (дата звернення: 20.04.2019 р.)

${ }^{28}$ Criminal Code of Austria 1975 (as last amended by Federal Law Gazette (BGBl) I № 33/2011). URL: https://www.legislationline.org/documents/section/criminal-codes/country/44/Austria/show. (дата звернення: 20.04.2019 p.)
} 
contradictory terminology, "physical inviolability", "physical injury" and "harm to health", raising a number of questions. Firstly, "physical injury" is any injury caused damage to the physical inviolability of the human body (even a prick with a needle causes damage); and secondly, the term "harm to health" is wider than the term "physical injury".

In this case, one article may have different consequences and different forms of guilt according to gravity degree. In addition, the Criminal Code of Austria established other features of physical injury as well. For example, grave physical injury ( $\S 84$ of the Criminal Code of Austria) is an act caused health harm that lasts more than twenty-four days, or loss of professional working capacity or physical injury or harm to health, which is grave itself. This article is significantly different from the provisions of Article 121 of the Criminal Code of Ukraine and has a lot of evaluative categories, which, in our opinion, make understanding of features of such injury difficult. Other features of grave physical injury are defined by Austrian lawmaker in $\S 85$ "Physical injury causing longlasting grave consequences", namely:

1) Loss of speech, vision, hearing or ability to childbirth or severe violations of these functions of the body;

2) Significant disfigurement that is visible, mutilation;

3) Severe suffering, chronic illness or loss of professional working capacity, forever or for a long time.

So, according to the name of the article, it is any physical injury, regardless of gravity degree, having the above features. The situation is the same in case of the victim's death $(\S 86$ of the Criminal Code of Austria).

In case of injured person's consent to infliction of physical injury, criminal liability is excluded if this does not contradict to generally accepted norms ( $\$ 90$ of the Criminal Code of Austria).

Criminal punishable is also the following:

1) Participation in a fight (Paragraph $1 \S 91$ of the Criminal Code of Austria), or if, as a result of the fight, a grave physical injury was committed ( $\$ 84$, paragraph 1 of the Criminal Code of Austria) or death to another person (paragraph $1 \S 91$ of the Criminal Code of Austria);

2) Causing physical or mental suffering to another person who has not reached the age of eighteen years or is defenseless as a result of their helplessness, illness or dementia and who is supported and in care of the 
person who commits the crime (Paragraph 1 of $\S 92$ of the Criminal Code of Austria).

So, a lawmaker of Austria identified a special victim, criminal liability is excluded in case of causing suffering to the "general" victim. In addition, as a special legal category in Austria criminal law, the term "with particular cruelty" is distinguished. Section 35 of the Criminal Code of Austria lists such crimes as "causing grave physical injuries with particular cruelty". It is these norms that are a certain novelty, since by 2007 these cases were considered separately and determined as component features of the objective side ${ }^{29}$.

The Criminal Code of the Republic of Bulgaria (hereinafter Bulgaria $)^{30}$ [28] in section II "Physical injury" in Articles 128-135 defines features and types of physical injuries.

The features of grave physical injury (Article 128 of the Criminal Code of Bulgaria) have certain differences from the features contained in Article 121 of the Criminal Code of Ukraine. Firstly, in Article 128 of the Criminal Code of Bulgaria a prolonged mental disorder is mentioned, the theory of criminal law stipulates about a mental illness that does not depend on its duration and degree of curability; and secondly, in the Criminal Code of Bulgaria, features of loss of pairs of organs are defined, but their list is incomplete, testicles, ovaries, organs of hearing, eyes are not determined. In addition, in case of loss of certain organ functions, qualification, in our opinion, will be carried out by the feature of a permanent general health disorder; thirdly, the mutilation that caused a permanent disorder of speech or the proper functioning of any organ of senses. This feature of grave physical injury is controversial. The organs of senses carry out the following types of sensitivity - touch, smell, taste, hearing, balance, and sight. In this case, the mutilation of senses as one of the features is duplicated by others - permanent blindness to one or both eyes, loss or maiming of a leg or an arm, loss of speech. In addition, the article does not refer to face mutilation, although most organs of the human senses are focused on the face (nose, eyes, and ears) and oral cavity (tongue).

\footnotetext{
${ }^{29}$ Assault, wounding and related offences. URL: https://www.judcom.nsw.gov.au/publications/ benchbks/sentencing/assault_wounding_offences.html) (дата звернення: 30.09.2017).

${ }^{30}$ Criminal Code of Bulgaria Publication State Gazette № 26 / 02.04.1968, in force as of 01.05.1968, Last amendment SG № 32/27.04.2010, in force as of 28.05.2010. URL: https://www.legislationline.org/documents/ section/criminal-codes/country/39/Bulgaria/show. (дата звернення: 20.04.2019р.)
} 
In case of physical injury of middle gravity, features of physical injury of middle gravity according to the Criminal Code of Bulgaria (Article 129 of the Criminal Code of Bulgaria) are sometimes similar to the features of grave physical injury defined in the Criminal Code of Ukraine, for example, a wound, penetrating into the skull, chest or abdominal cavity. According to the Criminal Code of Bulgaria, some features of grave physical injury duplicate the features of physical injury of middle gravity - maiming legs or arms (Article 128 of Bulgaria) and facial or other body mutilation (Article 129 of Bulgaria). The question about temporarily life-threatening health disorder arises.

Trivial physical injuries (paragraph 1, Article 130) are all other injuries that do not fall under the features defined in Article 128 and 129 of the Criminal Code of Bulgaria. In case of causing pain or suffering without a health disorder, criminal liability arises according to par. 2 Article 130 of the Criminal Code of Bulgaria. In Article 131 qualifying features for physical injuries of any degree of gravity are provided separately.

In case of causing any physical injury in excess of the limits of necessary defense and in a state of intense emotional distress caused by violence, severe abuse, slander or other illegal action on the part of the victim, which resulted in or could be resulted in severe consequences for the guilty person or their relatives, criminal liability is provided in one article (Article 132) of the Criminal Code of Bulgaria. Careless infliction of grave physical injury or physical injury of middle gravity is defined in Article 133 of the Criminal Code of Bulgaria.

After comparing the articles (Article 133 of the Criminal Code of Ukraine and 135 of the Criminal Code of Bulgaria) providing for criminal liability for contamination of sexually transmitted diseases, the results show that their difference is that in Bulgaria a lawmaker determines the way of putting into danger of contamination - by sexual intercourse or in other way. This feature, in our opinion, can not affect the qualification formula, therefore it is not appropriate.

\section{CONCLUSIONS}

Therefore, according to the Criminal Code analysis results it can be stated that legal acts on criminal liability of certain foreign countries protect person's health to a different extent. It is determined by the fact 
that not all Criminal Codes contain norms providing criminal liability for "blows and torment", "torture", "contamination with sexually transmitted diseases" etc. In the articles of the Criminal Codes examined, the limits of physical injuries are "washed out" or their features are sometimes duplicated because they stipulate criminal actions (violent actions, attacks) without further concretization of criminal consequences in the article.

At the same time, it should be mentioned that the best Codes, containing the largest amount of norms designed to protect health, are the Criminal Code of France because it reveals their features in a clearest way, the Criminal Code of Bulgaria and some Criminal Code of the postSoviet countries. In general, some provisions of the foreign Criminal Codes are the example for its succession in the national criminal law.

\section{SUMMARY}

The fact that Ukraine was a part of the former Soviet Union for some decades influenced the legislation on criminal liability. It determined the direction of criminal law development, and after Ukrainian independence acquiring, defined the necessity for its changes and essential improvement. So, carrying out comparative legal analysis of crimes against health in some countries of Romano-Germanic legal family, we would like to mention, that certain provisions of foreign criminal legislation is an example for their succession in national criminal legislation.

\section{REFERENCES}

1. Criminal Code of the Republic of Belarus. №. 275-Z of 9 July, 1999 (as amended up to July 12, 2013). URL: http://cis-legislation.com/ document.fwx?rgn=1977. (дата звернення: 20.04.2019 p.).

2. Criminal Code of the Republic of Moldova. № 985 of April 18, 2002. (as amended up to November 11, 2016). (MD138). URL: https://sherloc.unodc.org/res/cld/document/criminal-code-of-the-republicof-moldova_html/Republic_of_Moldova_Criminal_Code.pdf. (дата звернення: 20.04.2019 р.).

3. The Criminal Code Of The Russian Federation No. 63-Fz Of June 13, 1996. URL: https://www.wipo.int/edocs/lexdocs/laws/ en/ru/ru080en.pdf (дата звернення: 20.04.2019 p.). 
4. Criminal Code of the Kyrgyz Republic No. 68 of October 1, 1997. (as amended up to Law No. 62 of April 21, 2014). URL: https://ihldatabases.icrc.org/applic/ihl/ihl-nat.nsf/0/705a3f3b34f0090ec 12577440047742c/\$FILE/Criminal\%20Code_en.pdf. (дата звернення: 20.04.2019 p.).

5. Criminal Code of Latvia, of March 14, 2002, Law No. IX-785 (Last amended on December 23, 2010, by Law No XI-1264). URL: https://likumi.lv/ta/en/id/88966-the-criminal-law. (дата звернення: 20.04.2019 p.).

6. Lithuanian Criminal Code, of March 14, 2002, Law No. IX-785 (Last amended on December 23, 2010, by Law No XI-1264). URL: https://wipolex.wipo.int/en/text/202109. (дата звернення: 20.04.2019 p.).

7. Criminal Code of the Republic of Armenia of April 18, 2003. URL: http://www.preventgenocide.org/am/criminalcode.htm. (дата звернення: 20.04.2019 р.).

8. The Code of the Republic of Kazakhstan dated 3 July 2014. № 226-V of the Law of the Republic of Kazakhstan. URL: https://wipolex.wipo.int/en/text/407059. (дата звернення: 20.04.2019 p.).

9. Criminal Code of the Republic of Tajikistan. URL: http://cislegislation.com/document.fwx?rgn=2324. (дата звернення: 20.04.2019 p.).

10. Penal Code of the Republic of Estonia (consolidated text of January 1, 2012). URL: https://wipolex.wipo.int/en/text/432563. (дата звернення: 20.04.2019 р.).

11. Criminal Code of the Republic of Uzbekistan 1994 (as amended up to Law of the Republic of Uzbekistan No. 93 of April 25, 2007). URL: https://sherloc.unodc.org/res/cld/document/criminal-code-of-the-republicof-uzbekistan_html/Uzbekistan_Criminal_Code_1994.pdf.

(дата звернення: 20.04.2019 р.).

12. Кримінальний кодекс України від 5 квіт. 2001 № 2341-III // Відомості Верховної Ради України. 2001. № 25-26. Ст. 131 (редакція від 26.02.2019 р.). URL: http://zakon3.rada.gov.ua/laws/show/2341-14.

13. Абдрашит А. А. Уголовная ответственность за умышленное причинение тяжкого вреда здоровью по законодательству Республики Казахстан: автореф. дис. ... канд. юрид. наук: спец. 12.00.08 «Уголовное право и криминология; уголовно- 
исполнительное право». Саратов: Акад. МВД Республики Казахстан. 2004. 24 c.

14. Кухарьков Ю. В., Самойлович М. В. Судебно-медицинская експертиза характера и степени тяжести телесных повреждений: учебно-метод. пособие. Минск, 2003. 26 с.

15. Инструкция о порядке проведения судебно-медицинской экспертизы по определению степени тяжести телесных повреждений от 24 мая 2016 г. № 16. URL: http://www.pravo.by/upload/docs/op/ T21603582_1475096400.pdf.

16. Хавронюк М. І. Кримінальне законодавство України та інших держав континентальної Європи: порівняльний аналіз, проблеми гармонізації. Київ: Юрисконсульт, 2006. 1048 с.

17. О внесении изменений и дополнений в некоторые законодательные акты Республики Казахстан по вопросам совершенствования правоохранительной системы // Закон Республики Казахстан от 3 июля 2017 г. URL: № 84-VI. https://zakon.uchet.kz/rus/docs/Z1700000084\#202.

18. Комментарий к Уголовному кодексу Республики Беларусь / Н. Ф. Ахраменко, Н. А. Бабий, А. В. Барков и др.; под общ. ред. А. В. Баркова. Минск: Тесей, 2003. 1200 с.

19. Правила судебно-медицинской экспертизы характера и тяжести телесных повреждений в Республике Беларусь от 14 нояб. 1991 г. № 200. URL: http://pravoby.info/docum09/part36/ akt36157.htm

20. Катеринчук Е. В. Проблемы соответствия уголовного законодательства в сфере запрета пыток международным стандартам // Идеал свободной человеческой личности: от международних пактов о правах человека к современной Конституции: материалы Междунар. науч.-практ. конф. (м. Минск, 16 дек. 2016 г.). Акад МВД Республики Беларусь. 2016. С. 76-78.

21. Кодекс України про адміністративні правопорушення (редакція від 07.02.2019 р.) // Відомості Верховної Ради Української РСР. 1984, додаток до № 51. Ст. 1122.

22. Criminal Code of Germany (2013). URL: https://www.gesetze-iminternet.de/englisch_stgb/englisch_stgb.html\#p0012 . (дата звернення: 30.09.2017 p.). 
23. Criminal Code of the French Republic (as of 2016). URL: https://eige.europa.eu/gender-based-violence/resources/france/frenchpenal-code-general-criminal-law-articles-221-2-222-3-222-5-222-10. (дата звернення: 20.04.2019 р.).

24. Penal Code of Spain (Organic Law No. 10/1995 of November 23, 1995, as amended up to Law No. 4/2015 of April 27, 2015). URL: https://wipolex.wipo.int/en/text/507602. (дата звернення: 20.04.2019 p.).

25. Spanish Constitution of 1978 «Constitution passed by the Cortes Generales in plenary meetings of the Congress of Deputies and the Senate held on October 31, 1978. Ratified by referendum of the Spanish People on December 7, 1978. Sanctioned by his majesty the King before the Cortes Generales on December 27, 1978».URL:http://www.congreso.es/ portal/page/portal/Congreso/Congreso/Hist_Normas/Norm/const_espa_te xto_ingles_0.pdf (дата звернення: 20.04.2019р.).

26. Criminal Code of Austria 1975 (as last amended by Federal Law Gazette (BGBl) I № 33/2011). URL: https://www.legislationline.org/ documents/section/criminal-codes/country/44/Austria/show. (дата звернення: 20.04.2019 р.).

27. Assault, wounding and related offences. URL: https://www.judcom.nsw.gov.au/publications/benchbks/sentencing/assault _wounding_offences.html) (дата звернення: 30.09.2017р.).

28. Criminal Code of Bulgaria Publication State Gazette № $26 /$ 02.04.1968, in force as of 01.05.1968, Last amendment SG № 32/27.04.2010, in force as of 28.05.2010. URL: https://www.legislationline.org/documents/section/criminalcodes/country/39/Bulgaria/show. (дата звернення: 20.04.22019р.).

\section{Information about the author: Katerynchuk K. V. \\ Candidate of Juridical Sciences,} Assistant Professor at the Department of Special Legal Disciplines of the Educational-Scientific Humanitarian Institute of the V. I. Vernadsky Taurida National University 33, Ivana Kudri str., Kyiv, Ukraine 